\title{
Editorial for volume 1 of Asian Journal of German and European Studies
}

\author{
Gyoergy Szell ${ }^{*}$ and Kwang-Yeong Shin
}

* Correspondence: gszell@uos.de University of Osnabrueck,

Osnabrueck, Germany
We are glad to announce the first volume of the new Asian Journal of German and European Studies. It is located at the new DAAD-Centre German and European Studies at Chung Ang University, Seoul, Republic of Korea. You may ask, are not there already quite a number of similar publications? However, as you will see our approach is quite different from the existing ones, in so far we are convinced that it is complementary and not just competing within a given domain.

The Asian Journal of German and European Studies (AJGES) is the academic journal published by the DAAD-Centre for German and European Studies (ZeDES) at Chung Ang University in Seoul/CAU in close cooperation with the DAAD-Centre for German Studies at Peking University/ZDS and the Centre for German and European Studies at Tokyo University/DESK. The major aims of the journal are to publish quality, peerreviewed scholarly research papers and information on Europe, especially Germany, in an interdisciplinary or intercultural perspective with the focus from North-East Asia, namely in the humanities and social sciences.

While Asia and Europe have been interconnected since the beginning of human history, they have been considered independently for thousands of years. With the advent of modern globalization, both world regions have experienced common and different institutional challenges. Asia and Europe need to share academic research on economic, political, social and cultural affairs. The AJGES promotes interdisciplinary, intercultural, and trans-regional studies on Europe, especially Germany.

. The journal appears yearly in English and comprises 24 articles.

- It is an open access electronic journal, so it is freely accessible to students and the general public.

- Each volume of the journal will have a thematic series topic with a special editor in charge.

- Other sections are: book reviews, reports, and news.

. The English is U.K. English.

- Each contribution includes abstracts in English as well in German.

- The journal is a peer-reviewed journal.

- It is registered as an ISSN-journal, with Google Scholar, OCLC and Summon by Serial Solutions, and it is intended to access the Social Sciences Citation Index (SSCI), Arts \& Humanities Citation Index (A\&HCI), SCOPUS and the National Research Foundation of Korea index. 
We launched this journal exclusively as an electronic publication. It is not only for cost reasons, but we will be quicker, the access in a global field is easier, and finally it is much more ecological.

Its international scientific council is constituted by outstanding scholars from diverse countries and scientific fields.

And we are fortunate that the well-known publisher Springer with its Science + Business Media Singapore branch takes the responsibility for the publication.

We are looking forward for stimulating scientific exchanges and welcome articles from all fields and corners of the world.

Received: 25 June 2015 Accepted: 15 March 2016

Published online: 25 May 2016

Submit your manuscript to a SpringerOpen ${ }^{\odot}$ journal and benefit from:

- Convenient online submission

- Rigorous peer review

- Immediate publication on acceptance

- Open access: articles freely available online

- High visibility within the field

- Retaining the copyright to your article

Submit your next manuscript at $\boldsymbol{\nabla}$ springeropen.com 